\title{
OPEN ACCESS PUBLISHING IN BUSINESS RESEARCH: THE AUTHORS’ PERSPECTIVE
}

Address correspondence to Bryna Coonin, Reference Librarian, J.Y. Joyner Library, East Carolina University, $5^{\text {th }}$ St., Greenville, NC 27858. E-mail: coonin@ecu.edu This study was funded in part by the 2009 ALA/RUSA BRASS Emerald Research Award.

\section{INTRODUCTION}

Open access $(\mathrm{OA})$ publishing is now accepted as an integral part of the emerging trends within scholarly communication. However, the greatest traction for open access publishing thus far has been gained in the sciences, particularly in the life and medical sciences, and in physics. The penetration of open access publishing has been much slower generally among disciplines in the social sciences (Coonin \& Younce, 2009a). Byron Anderson explains some of the reasons for the rise of $\mathrm{OA}$ in the sciences - excessive subscription prices and the willingness of scholars within the sciences to seek alternatives for faster and wider dissemination of their research. In addition, medical and life sciences researchers are often recipients of federal funding, which results in taxpayers paying twice for the output of this type of research - first in the provision of the grant funding, and again when accessing the results in commercially-published scholarly literature (B. Anderson, 2004).

Open access research is most concisely defined as content that presents no barrier to the reader (financial or otherwise) other than access to the Internet itself (Budapest Open Access Initiative, 2002). Thus, if a researcher discovers an article in a fully open-access journal, the content of that article will be freely available. It is useful to note that while the principle of open access is concise (the results of research is freely available to the reader), open access publishing comes in a variety of what John Willinsky has termed "flavors." Willinsky offers up ten of these, based on the economic model used to support the publication. The variations range from partially accessible journals and journals operating with delayed/embargoed access to fully and immediately accessible journals such as those gathered in the Directory of Open Access Journals (Willinsky, 2005). 
The Budapest Open Access Initiative of 2002 suggests two major strategies to achieve open access to research. The first is self-archiving of refereed journal articles in freely available electronic archives, such as university institutional repositories, or discipline-based archives. The second is the publication of refereed open access journals (Budapest Open Access Initiative, 2002). A sizable body of research has developed around the strategy of self-archiving and repositories, and research attempting to measure the impact of open access publishing is also building. However, at this time fairly limited research is available reflecting the viewpoint of authors concerning publishing in open access journals. Where this does exist, it tends to concentrate heavily on the sciences rather than on the social science disciplines (Coonin \& Younce, 2009a).

Arthur Sale points out that faculty actively engaged in research take on two different guises relative to open access - they wear two "hats" - depending on which phase of their research they are in. While they are looking for information about the research topic they are searchers. When the research is complete they move into the role of disseminator - that of author. As academic librarians we are used to dealing with the searcher. Increasingly though, as publishing models are changing, we are called upon to engage with faculty as authors. This role is somewhat less familiar, and going forward, we will need more data about how researchers behave when in author mode, during which they are responding primarily to the expectations of peers in their discipline (Sale, 2006).

While authors are in the process of searching for research articles -- while they remain in Arthur Sale's "searcher" phase-they readily accept the valuable convenience that open access publishing makes possible for the reader. Rick Anderson cautions that convincing people to read open access articles isn't the problem. "If high-quality content is available it will tend to get used...the issue is attracting authors, especially in the 'early going' when authors have other publishing alternatives" (R. Anderson, 2004). At this juncture, business research is still in the 
'early-going' stage with respect to open access publishing. Thus, it may be unclear to many authors of business research whether $O A$ is at the edge of a viable publishing trend, or still on the fringe of it.

\section{RELEVANT LITERATURE}

Nicholas and Rowlands point out that, as of 2003/2004, the discussion surrounding open access took into account viewpoints of open access advocacy groups, publishers, and librarians... "but what was largely missing were the views of the authors, arguably the most important stakeholder group." (Nicholas and Rowlands, 2005).

In 2004, U.K. authors Alma Swan and Sheridan Brown, on behalf of the Joint Information Systems Committee (JISC) and the Open Society Institute (OSI), surveyed 154 authors who published in open access journals and 157 who had not (Swan and Brown, 2004). Swan and Brown investigated authors' awareness of open access, and their experiences of publishing their work as OA. Swan and Brown also explored authors' concerns about the implications open access publishing may have for their careers, and the reasons why (or not) they chose to publish through an open access outlet. Among their findings was a very high percentage (90\%) of open access authors who said their primary reason for choosing an open access journal was the principle of free access to research information. The non-OA group believed that open access journals were of lower reputation and prestige. Both groups had some concerns that publishing in an open access journal would affect their chance of winning research grants. The Swan and Brown survey included authors internationally and across a number of disciplines, but numbered only a very small selection of authors in the social sciences category (Swan and Brown, 2004).

David Nicholas, Paul Huntington, and lan Rowlands sought to determine wellestablished authors' attitudes toward OA publishing. Surveying nearly 4,000 senior authors from 97 countries, this was the largest author survey conducted concerning OA publishing. One 
of the most striking findings to emerge from this study was the general ignorance of OA publishing among the senior authors surveyed. In addition, real differences of opinion and practice emerged among authors of different disciplines. Like Swan and Brown, however, the disciplines covered were largely concentrated in the sciences, with a very small percentage of respondents from the social sciences of any kind (Nicholas, Huntington, and Rowlands, 2005).

In March 2009 Bryna Coonin and Leigh Younce presented the results of their study of the perspectives on OA publishing of selected social science and humanities researchers to the $14^{\text {th }}$ National Conference of the Association of College \& Research Libraries in Seattle, and subsequently published their findings in the proceedings of this conference (Coonin and Younce, 2009a). This study surveyed 918 authors from 2007-2008 issues of open access journals in psychology, business management, women's studies, and music. In 2009 the authors repeated the original study focusing this time on academic researchers in the field of education (Coonin and Younce, 2009b). The data from these two studies suggest that peerreview will remain key to the decision of where to publish, regardless of the business model used for publishing. However, the data also suggests that an understanding (and acceptance) of open access journal publishing as a viable outlet for scholarly publishing is still quite dependent on the research and publishing culture within the disciplines. For authors working in the nonscience disciplines especially, it seems likely that open access may take a while to reach fuller acceptance, if it does. More discipline-related research was clearly needed concerning open access publishing in the social sciences. Thus the decision was taken to continue studying this issue by repeating the original study, focusing this time on researchers in the field of business.

\section{METHODOLOGY}

This study surveyed business faculty from American schools of business accredited by the Association to Advance Collegiate Schools of Business (AACSB) as of July 2009. Schools of all sizes were included, with geographic representation from fifty states and the District of 
Columbia. The mailing list was compiled by hand from university websites. The URL for the web-based survey, delivered via SurveyMonkey, was successfully e-mailed to 19,466 business faculty beginning in late Fall 2009 and ending in early 2010. The survey closed on May 10, 2010 , with 1,293 respondents, for a response rate of $6.6 \%$. While the number of respondents may not represent a highly statistically significant sample, it does allow for a meaningful conversation about publishing practices with a sizable cross-section of business research faculty across the United States. (Appendix)

\section{FINDINGS AND DISCUSSION}

The first segment of the survey sought information about the authors and their own publishing practices.

\section{$\underline{\text { Age and academic status }}$}

It was important to establish the age of respondents as the existing literature indicated that age may be a factor in perceptions concerning open access publishing (Nicholas, Huntington, and Rowlands, 2005). Of the 1,285 respondents to this question $1.8 \%$ were under 30 years old, $29 \%$ were between $31-45$ years old, $46.3 \%$ were age $46-60$, and $22.9 \%$ were 61 years or above.

Whether or not an individual is tenured was determined to be relevant particularly where concerns are voiced concerning the acceptability of open access publication in the tenure and promotion process. Of the 1,290 respondents to this question the majority $(66.1 \%)$ were tenured; $28.1 \%$ were tenure-track. "Other" (1.1\%) identified themselves as adjunct instructors or visiting professors. (Figure 1) 


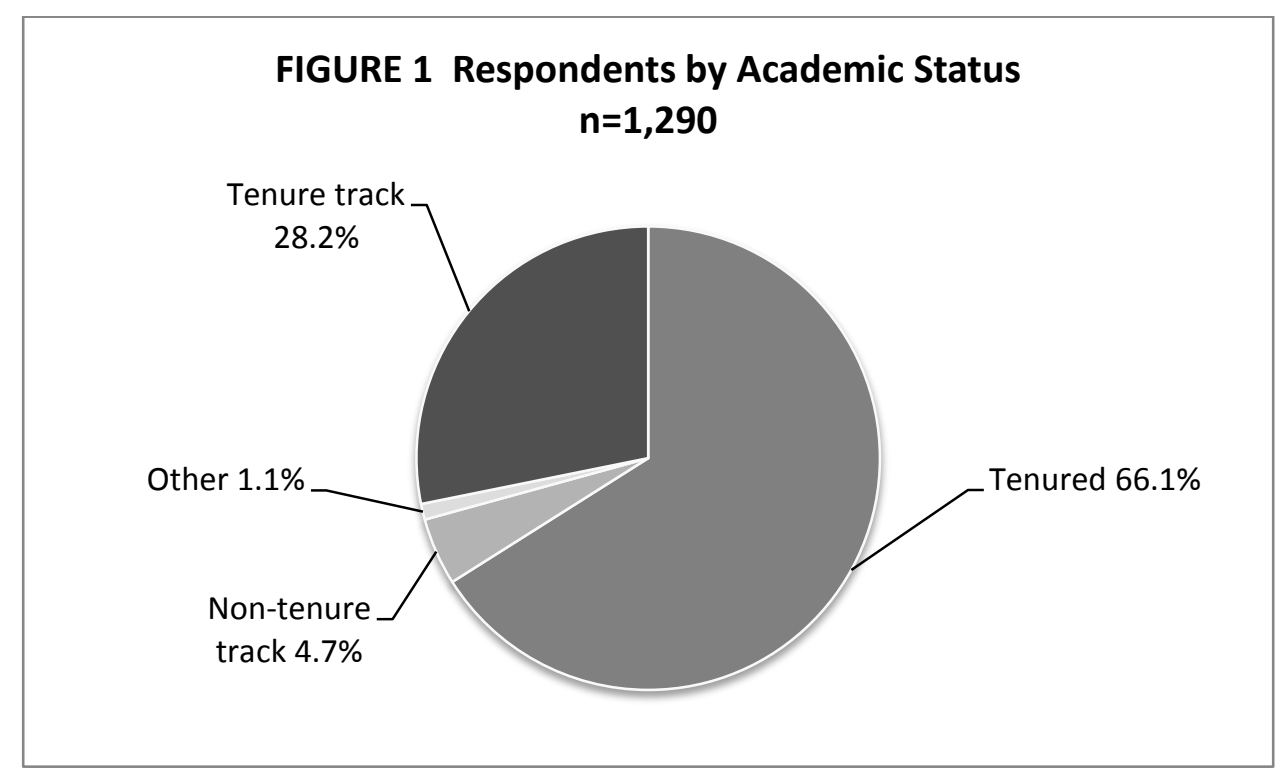

Article output - how many articles published thus far?

Nicholas and Rowlands found that prolific authors were more likely to publish in open access journals (Nicholas and Rowlands, 2005). Of the 1,289 respondents to this question $17.8 \%$ have published fewer than five scholarly articles; $18.4 \%$ have published between $5-10$ articles; $22.2 \%$ reported $11-20$ articles, and $41.6 \%$ have published more than twenty scholarly articles.

Important factors in deciding where to publish

Of the 1,288 respondents to this question the greatest importance by far was attached to peer review. Next in importance indicated was the reputation of the journal, followed closely by whether the journal was "a good match" for the author's research. Lining up behind these, in order of importance, were the quality of the editorial board, timeliness of publication, citation impact, and acceptance rate. Whether the venue is a scholarly society publication, whether the author has published there before, the ability to retain copyright, and lastly, the influence of a grant-awarding body were all reported in order of importance. (Figure 2) 


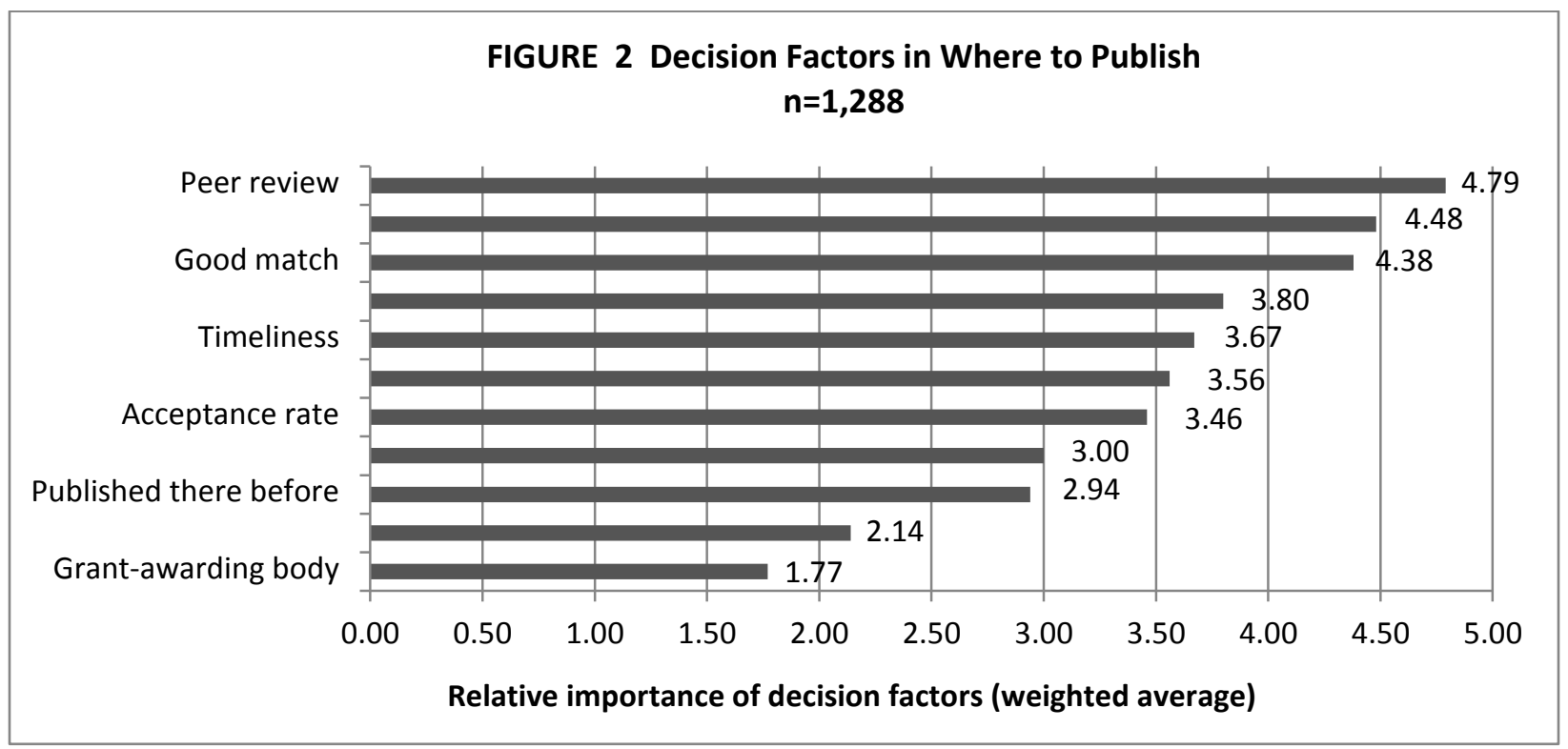

The relative lesser importance of citation impact is of interest. Queries concerning journal citation factors, such as the ISI impact factor, are very familiar to academic librarians. Faculty members often request information about citation impact to help support their position during the tenure-seeking process. Research is still developing around the somewhat controversial issue of citation impact as it relates to open access (Open Citation Project, 2009). The ability to retain copyright was of little importance to respondents. This is a significant finding because, as subject liaisons offering information about open access (perhaps in the context of encouraging deposit into an institutional repository), we may be speaking with faculty authors about retaining their rights. Retention of authors' rights is clearly important to us as librarians, but may not seem important to business faculty. They may not know it is possible for them to retain their rights, or initially see why it might be desirable.

The next segment of the survey explored how authors obtained articles needed for their own research.

Where do you most often get articles needed for your own research?

Of the 1,287 respondents $88.2 \%$ reported most often procuring articles through their library, both in print and electronically; $6.7 \%$ said they got articles freely "over the Internet"; $3.1 \%$ 
had personal subscriptions to the journals they needed, and $0.4 \%$ used articles or pre-prints sent to them by colleagues. Of the $1.6 \%$ who responded "other" the accompanying comments indicate that they fairly evenly use a combination of the options offered. One respondent specifically mentioned using the open access archive Social Sciences Research Network.

\section{(Figure 3)}

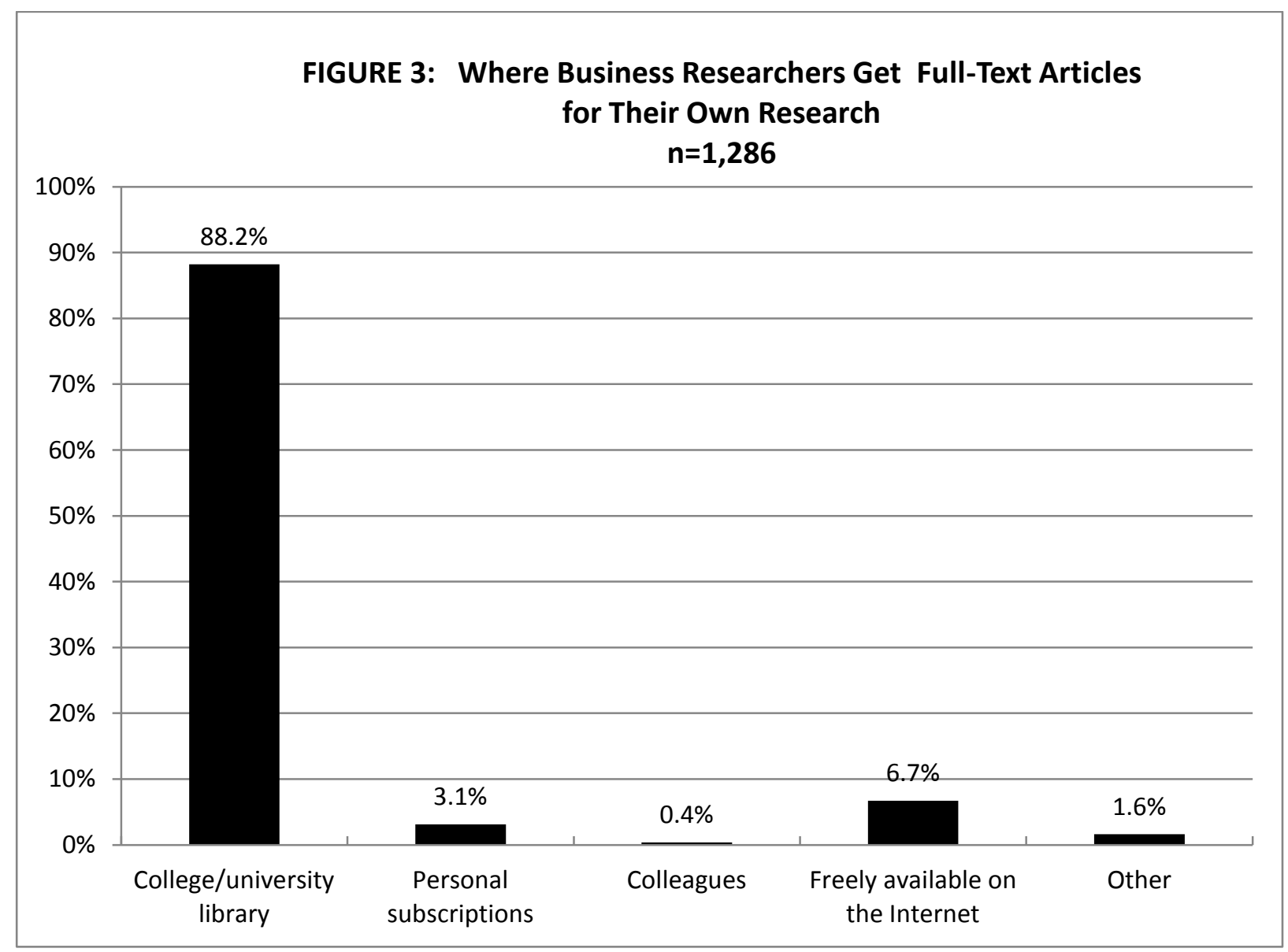

As you gather articles for your research, rank the importance of the following

Of the 1,288 respondents, $89.4 \%$ said that 'relevance to my work' was very important, with $32.3 \%$ indicating that the reputation of the journal was very important. Only a small percentage (3.0\%) indicated that journal reputation was not important. Of the 1,288 respondents $18.7 \%$ indicated that the reputation of the authors was most important, independent of the publication. 
The third segment of the survey asked about publishing practices within the discipline itself, including the acceptability among business faculty of electronic publication. Acceptability of electronic publication

Of the 1,263 respondents to this question $16.2 \%$ found publication in electronic journals acceptable; $10.1 \%$ found this not acceptable; $42.0 \%$ said doing so was less acceptable than print, and $31.6 \%$ indicated that format was not an issue - that other factors (e.g., peer review or the prestige of the journal) are more important. (Figure 4)

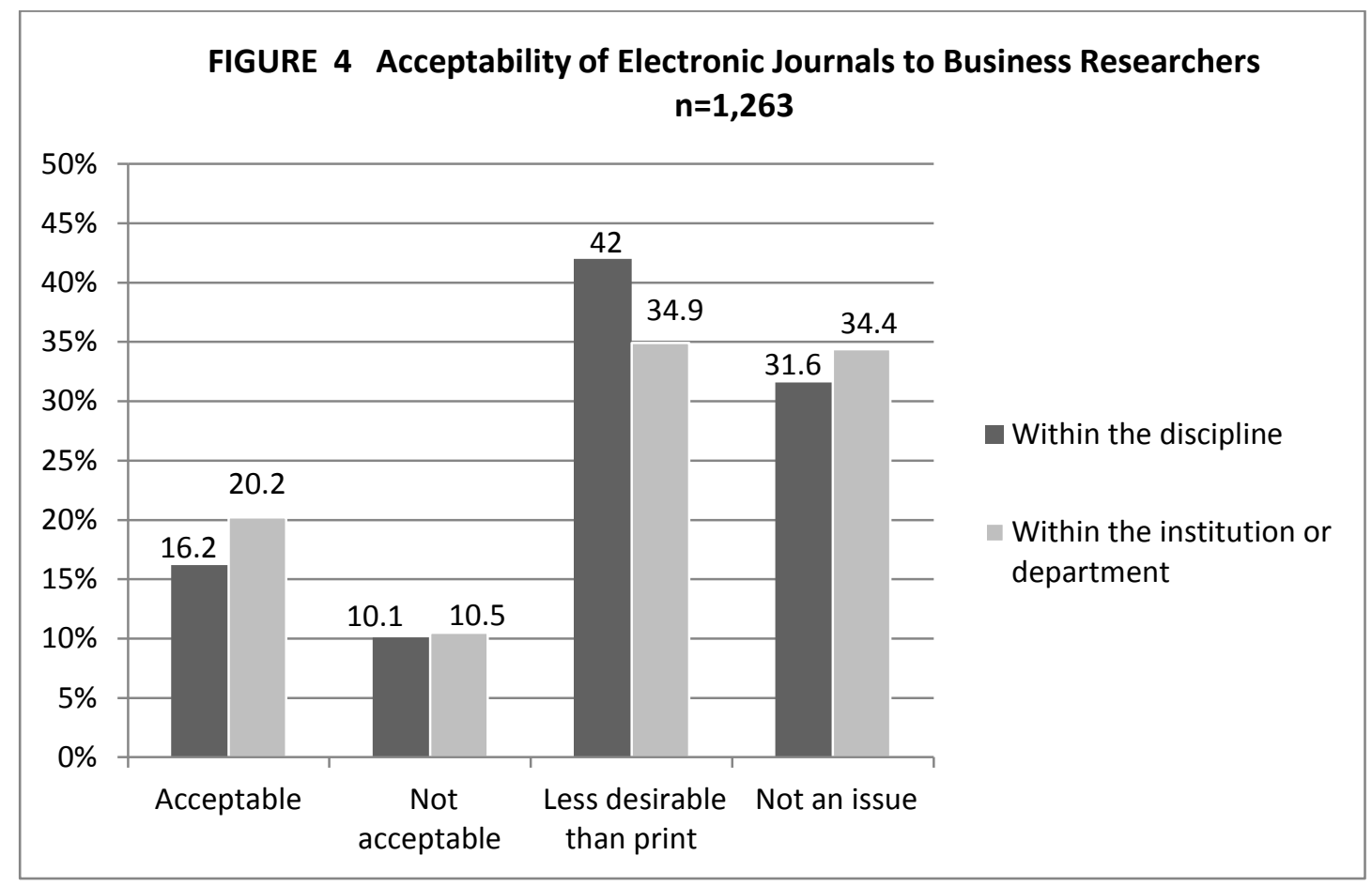

While acceptance of electronic publication among business faculty has not fully taken hold, it has grown over the past decade. In 1999, the Journal of Business \& Finance Librarianship published a study on fifty-two business faculty members' perceptions of the advantages and disadvantages of electronic journals (Hahn, Speier, Palmer, and Wren, 1999). Hahn's respondents understood the potential advantage of broader distribution that electronic journals offered. However, acceptance was seriously tempered by the respondents' perception 
at that time that e-journals are not always refereed and that they represented an increased potential for plagiarism.

Fast-forwarding ten years, the ITHAKA S+R 2009 Faculty Survey found that, among social sciences faculty queried, slightly more than $40 \%$ said they were now completely comfortable with the journals they use regularly ceasing print altogether and publishing only in electronic format. The ITHAKA S+R 2009 Faculty Survey also revealed that while faculty have grown increasing comfortable with the idea of the journals they use regularly ceasing to arrive locally in print, they are less comfortable with the journals they rely on switching to a solely electronic version (Schonfeld and Housewright, 2009). Diane Harley of the Berkeley Center for Studies in Higher Education indicates that one reason for this may be that faculty view the print version as setting limits on a journal's acceptance rate, which can be a key factor in establishing the prestige of a journal (Harley, 2010).

The results for business faculty surveyed for this article tracks fairly closely to what ITHAKA 2009 reported for social scientists. The total business faculty who found electronic journal publishing acceptable (including those who indicated that format was not an issue) came to $47.8 \%$ of respondents. This level of acceptance remained fairly uniform among the subdisciplines within business. (Figure 4a) 


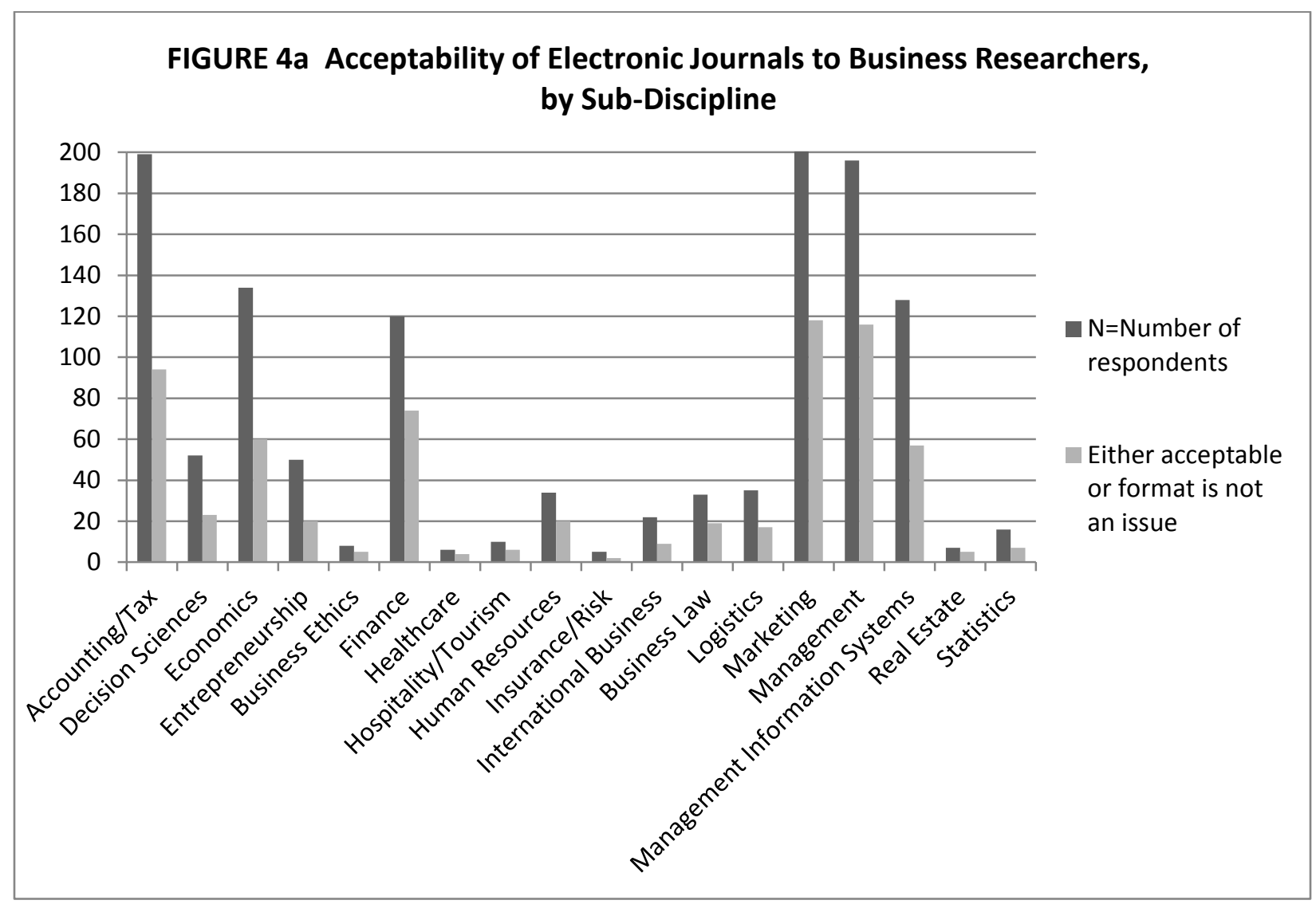

Type(s) of publication most important for advancement in the discipline

Among the 1,275 respondents to this question, publication in peer-reviewed journals was considered by far the most important type of publishing, with $98.8 \%$ of respondents indicating this was "important" or "very important." A precipitous drop follows, with book/monographs the next in comparative importance (32.0\%). Conference proceedings, book chapters, textbooks, case studies, trade journals, pre-prints/working papers fall in behind. Book chapters and abstracts were perceived as least valued for advancement in the discipline. (Figure 5) 


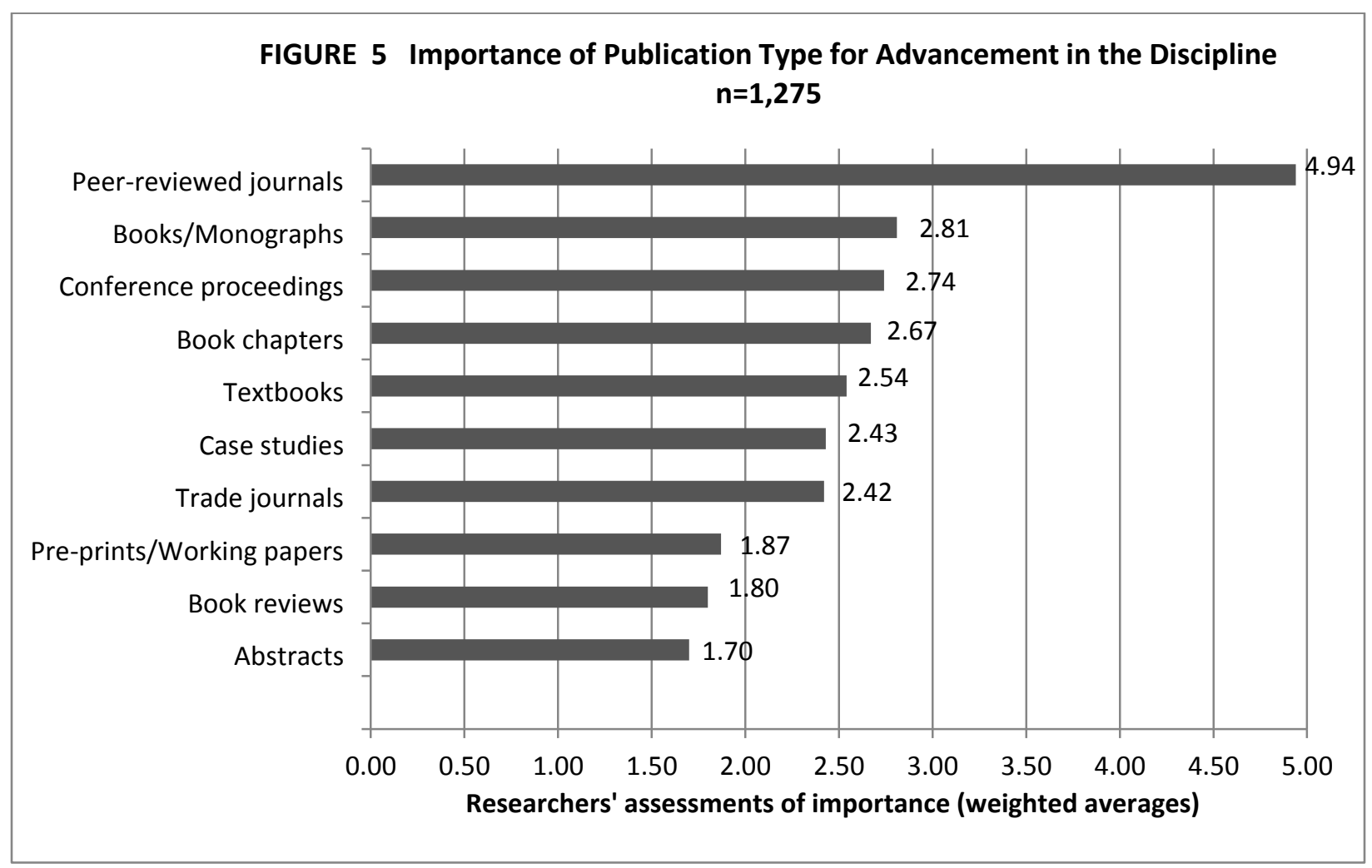

The next survey segment examined how respondents became aware of $O A$, and explored some of their perceptions about open access publishing.

\section{How respondents became aware of $O A$}

Of the 1,257 respondents $34.3 \%$ indicated that this survey was the 'first they've heard of it'; searching the Internet for publishing opportunities came in next at $22.9 \%$; reading an article in a newspaper or magazine registered at 18.7\%; $14.4 \%$ were introduced by a colleague; $10.3 \%$ were informed by a professional society; only $7.9 \%$ found out about OA through their library, 4.7\% from their institution/university (but not the library); $0.2 \%$ from a funding agency. The category "Other" attracted $12.4 \%$. The comments associated with this response were largely of the "I don't remember" variety.

The relatively low number becoming aware through a funding agency is significant because it highlights that discipline really does matter when discussions of OA are at hand. Health and medical researchers working regularly with federal funding from the National 
Institutes of Health $(\mathrm{NIH})$ will be familiar with $\mathrm{OA}$ because $\mathrm{NIH}$ is responsible for a major and widely-publicized OA mandate, the National Institutes of Health Public Access Policy (National Institutes of Health, 2008). Business researchers will be less likely to routinely conduct research using federal funding. They are thus less likely to intersect with federal mandates, although it is of interest to note at this juncture that two major business schools have adopted open access policies. The MIT Sloan School of Management approved an open access policy in March 2009. The Harvard Business School (HBS) approved an open access policy on February 12, 2010. Under this policy, HBS faculty agree to include scholarly articles in the university's institutional repository and grant the university permission to distribute the articles as long as they are not sold for a profit (Free, 2010).

The library's limited role, as reported by the respondents, gives further credence to Arthur Sale's assertion that researchers are used to having librarian assistance in the research stage of a project, but are not as accustomed to librarian involvement when they are preparing to publish their work (Sale, 2006). (Figure 6)

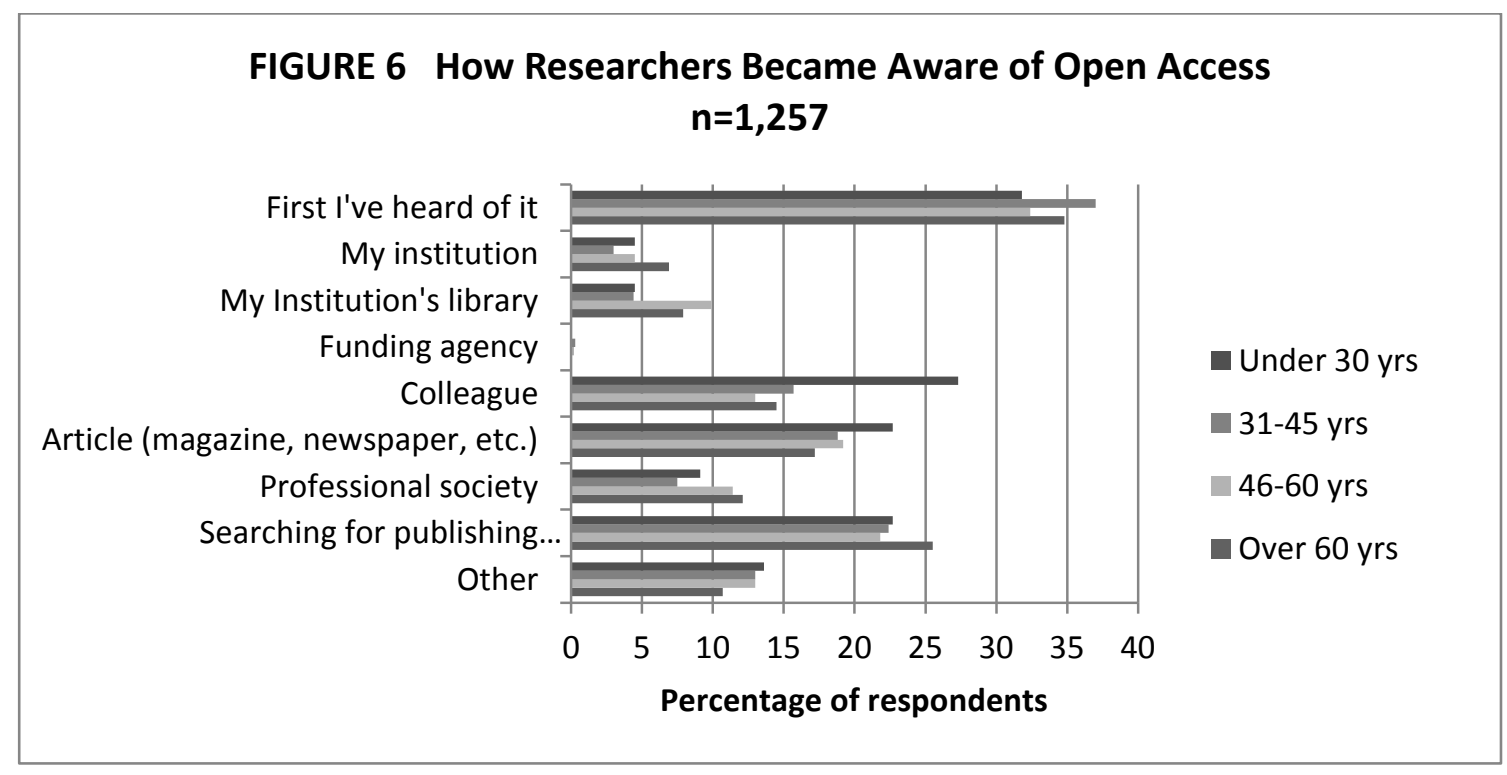

Perceptions of OA publishing 
The responses to this question indicate that there is room for fruitful discussions between business librarians and their faculty about various aspects of open access publishing. Of the 1,256 respondents to this question $72.8 \%$ understood that OA would mean free access for readers; only $2.1 \%$ believed that OA would not mean free access for all; $16.5 \%$ said it depends on the journal, $8.6 \%$ had no opinion.

Opinions were split on the issue of whether OA would engender faster publication, with $50.3 \%$ saying it would, $2.6 \%$ saying it would not, $25.1 \%$ saying it depends on the journal; $22.0 \%$ had no opinion. Mixed reaction to the issue of speedier publication is understandable. Editorial work, peer review, layout, etc. all take time, regardless of the format or publishing model of a publication. Many authors would be cognizant of this, although perhaps not certain how much of a factor it might prove to be.

Of the respondents to this question $26.6 \%$ thought readership would be larger, with $16.7 \%$ saying they did not think this would be the case. The highest percentage (38.3\%) said it depends on the journal; $18.4 \%$ had no opinion. Concerning the issue of whether articles would be more frequently cited $11.5 \%$ thought they would; $31.1 \%$ said they would not; $37.3 \%$ said it depends on the journal; $20 \%$ had no opinion. Concerning subscription costs, a healthy majority of respondents (62.6\%) thought OA would reduce the cost of subscriptions; $11.0 \%$ thought it would not reduce subscription costs; $8 \%$ said it depends on the journal; $18 \%$ had no opinion. Of the respondents, $55.5 \%$ thought OA journals were less prestigious than subscription-based journals. Only $6.1 \%$ said they were not less prestigious; $27.1 \%$ said it depends on the journal, and $11.3 \%$ had no opinion. This issue of perceived prestige is important because it can impact whether OA publication becomes a mainstream activity within a discipline.

Proper archiving is often mentioned as a concern with OA publication. Of the respondents $8.5 \%$ believed open access journal articles would not be properly archived; $34.2 \%$ said believed OA articles would be properly archived; $20.3 \%$ said it depends on the journal. A 
fairly high number (37\%) had no opinion. When asked whether OA would adversely affect the viability of scholarly societies, $17.3 \%$ thought it would; $35.7 \%$ thought it would not; $12.2 \%$ said it depends on the journal; $34.8 \%$ had no opinion.

Of the responses to the assertion that OA "may adversely affect chances of promotion" $27.3 \%$ said they believed it would adversely affect chances of promotion; $25 \%$ said it would not; $25.1 \%$ said it depended on the journal; $22.7 \%$ had no opinion. The last statement offered - "OA journals are usually not peer-reviewed" -- garnered $11.8 \%$ saying true; $29.8 \%$ saying false; $32 \%$ indicating that it depends on the journal; 26.4\% had no opinion. (Figure 7)

FIGURE 7 Business Researchers' Perceptions of Open Access Publishing $n=1,256$

\begin{tabular}{|c|c|c|c|c|}
\hline & TRUE & FALSE & $\begin{array}{c}\text { DEPENDS } \\
\text { ON THE } \\
\text { JOURNAL }\end{array}$ & $\begin{array}{c}\text { NO } \\
\text { OPINION }\end{array}$ \\
\hline OA means free access for all readers & $72.8 \%$ & $2.1 \%$ & $16.5 \%$ & $8.6 \%$ \\
\hline OA journals have faster publication times & $50.3 \%$ & $2.6 \%$ & $25.1 \%$ & $22.0 \%$ \\
\hline Readership will be larger & $26.6 \%$ & $16.7 \%$ & $38.3 \%$ & $18.4 \%$ \\
\hline Articles will be more frequently cited & $11.5 \%$ & $31.1 \%$ & $37.3 \%$ & $20.0 \%$ \\
\hline
\end{tabular}




\begin{tabular}{|c|c|c|c|c|}
\hline $\begin{array}{l}\text { OA publishing will help reduce cost of publication } \\
\text { subscriptions }\end{array}$ & $62.6 \%$ & $11.0 \%$ & $8.0 \%$ & $18.5 \%$ \\
\hline $\begin{array}{l}\text { OA journals are less prestigious than subscription } \\
\text { based journals }\end{array}$ & $55.5 \%$ & $6.1 \%$ & $27.1 \%$ & $11.3 \%$ \\
\hline OA journals will not be properly archived & $8.5 \%$ & $34.2 \%$ & $20.3 \%$ & $37.0 \%$ \\
\hline $\begin{array}{l}\text { OA journals may adversely affect the viability of } \\
\text { scholarly societies }\end{array}$ & $17.3 \%$ & $35.7 \%$ & $12.2 \%$ & $34.8 \%$ \\
\hline May adversely affect chances at promotion & $27.3 \%$ & $25.0 \%$ & $25.1 \%$ & $22.7 \%$ \\
\hline OA journals are usually not peer reviewed & $11.8 \%$ & $29.8 \%$ & $32.0 \%$ & $26.4 \%$ \\
\hline
\end{tabular}

\section{Author publication fees}

Of the 1,247 respondents, $32.8 \%$ said they have published in publications that required author fees; $5.8 \%$ said they had not done so but they would; $26.9 \%$ said they had not done so but would do so depending on the journal and the purpose of the fee; $10.2 \%$ said they would do 
it if a funding agency or institution paid for it; $24.4 \%$ said they would not publish in journals that required publication fees.

This question garnered heated comments - more so than any of the other questions in the survey that allowed for comments. The percentage of respondents who indicated they would not pay a fee under any circumstances may be a function of how common (or uncommon) this practice is within the discipline. Author publication fees are fairly commonplace among journals in the life and medical sciences, where grant funds often cover these costs. The practice is less common among academic business publications. A number of respondent comments distinguished between submission charges and publication fees required postacceptance (for color graphics, for example). Submission charges per se were not anathema, but there was some concern expressed that if charges intersected in any way with the review process these charges would be unacceptable. Several of the comments received indicated that for some, author publication fees are equated with 'vanity' publishing.

The final segment of the survey concentrated upon issues surrounding self-archiving. Respondent authors were asked whether they had themselves self-archived (on a personal website, in an institutional repository, in an e-print archive, etc.) Of the 1,259 respondents to this question, $31.5 \%$ indicated they have self-archived one or more of their publications (on a personal website, institutional repository, e-print archive, etc.); $68.5 \%$ have not self-archived. This was intriguing because Nicholas et al reported that those making scholarly materials available on their own web page or depositing in an institutional archive were about one and a half times more likely to publish in OA journals (Nicholas, Huntington and Rowlands 2005). Clearly it is not automatically the case, though, that authors publishing in open access journals also self-archive.

Of those who did self-archive $76.1 \%$ did so to make their research more widely available; $38.7 \%$ indicated that they believe it will increase the impact of their research; $16.5 \%$ 
said the decision was influenced by the institution/department/library; $1.0 \%$ said the grantawarding body required it; $5 \%$ said their co-authors were influential in the decision to selfarchive. The remaining $14.5 \%$ said "other" and left comments. These reasons expressed in the comments included the need to provide documentation for AASCB accreditation, and the personal desire to keep a readily-available file of what he/she had published. One respondent mentioned the desire to increase their visibility for possible future job searches. This may mean that at least some of the authors surveyed self-archived occasionally or opportunistically rather than comprehensively.

Business librarians may also be interested in those who said they did not self-archive and why. Fifty-seven percent of those who did not self-archive said they didn't actively choose not to - it just had not come up. Nineteen percent said they were not convinced it would be an advantage to do so. Seventeen percent said they were not certain copyright allowed it; $8.8 \%$ said their institution did not have a repository available; $20.8 \%$ said they were not sure where or how to do so; $13.4 \%$ said they do not have the time. Five percent said "Other." From the comments that accompanied these "other" responses it was clear that a number thought selfarchiving was instead of publishing in journals and that journals would look upon it as prior publication. The misunderstandings about self-archiving were rife, so business librarians may wish to be aware of this when discussing self-archiving with faculty.

\section{CONCLUSIONS}

Scholars work and teach in institutions, but the vitality of their scholarly lives is derived from the reception of their work by peers within their disciplines. The business researchers surveyed confirmed that peer review is of primary importance in their publishing activity.

There remains some confusion regarding the issue of electronic journal versus print publishing. For business librarians discussing open access publishing with faculty, it may be important to establish clearly that the concept of open access is not the same as a format 
change from print to electronic. Another potential source of confusion arises from self-archiving. A major trend within the scholarly communication arena, self-archiving appears to respond to somewhat different stimuli than the impulse to engage in OA publishing. Business librarians working with faculty on these issues cannot assume that participation in one of these activities automatically implies interest in the other.

Increasingly, open access overall represents a leading edge in scholarly publishing rather than the "fringe." However, an understanding (and acceptance) of open access journal publishing as a viable outlet for scholarly publishing is still quite dependent on the research and publishing cultures within the disciplines. It may be helpful for business librarians to keep in mind that issues concerning open access often crystallize at different times for different individuals. For some, clarification develops as scholars become more aware of scholarly communication generally. Others may give the matter little or no thought until open access is discussed in a forum within their narrow discipline, among colleagues they hold in high regard.

In a recent study of academic librarians' attitudes about open access Palmer, Dill, and Christie indicate that librarians "appear to be more comfortable with tasks that translate traditionally held responsibilities, such as educating others, to the open access environment" (Palmer, Dill, and Christie, 2009). Advocacy for open access is the ideal, but such a stance may not be possible for every business librarian. Increasing awareness of open access among our academic faculty, however, remains an important and reasonable goal for librarians serving business faculty.

\section{FURTHER RESEARCH}

In an earlier open access study the authors found indications that the academic discipline plays a role in the willingness of authors to publish in an open access environment (Coonin and Younce, 2009a). Open access publishing trends cannot be fully understood without more detailed, thoughtful investigation along discipline-related lines. Additional studies of 
authors' perspectives within very specific disciplines would provide useful insights both for researchers in these disciplines as well as for the academic librarians who serve them.

\section{REFERENCES}

Anderson, B. (2004). Open access journals. Behavioral \& Social Sciences Librarian 22(2), 93-99.

Anderson, R. (2004). Author disincentives and open access. Serials Review 30(4), 288-291.

Budapest Open Access Initiative (2002). Retrieved February 5, 2010, from: http://www.soros.org/openaccess/read.shtml

Coonin, B. and L. M. Younce. (2009a). Publishing in open access journals in the social sciences and humanities: Who's doing it, and why? In Pushing the Edge: Proceedings of the fourteenth national conference of the Association of College and Research Libraries, March 12-15, 2009, Seattle, Washington, ed. Dawn Mueller, (pp.85-94). Chicago: American Library Association.

Coonin, B. and L. M. Younce. (2009b). Publishing in open access education journals: The authors' perspectives. Behavioral \& Social Sciences Librarian 29(2), 118-132.

Free, D. (2010). OA at Harvard Business School. C\&RL News 71(4), 183.

Hahn, S.E., Speier, C., Palmer, J., \& Wren, D. (1999). Advantages and disadvantages of electronic journals. Journal of Business \& Finance Librarianship 5(1), 19-33.

National Institutes of Health. (2008). NIH Public Access Policy. Retrieved September , 2010, from: http://publicaccess.nih.gov/policy.htm .

Nicholas,D. and I. Rowlands. (2005). Open access publishing: The evidence from the authors. Journal of Academic Librarianship 31(3), 179-181.

Nicholas, D., P. Huntington, and I. Rowlands, (2005). Open access journal publishing: The views of some of the world's senior authors. Journal of Documentation 61(4), 497-519.

Open Citation Project (2009). The effect of open access and downloads ('hits') on citation impact: a bibliography of studies. Retrieved March 15, 2010, from: http://opcit.eprints.org/oacitation-biblio.html

Palmer, K., E. Dill, and C. Christie. (2009). Where there's a will there's a way?: Survey of academic librarian attitudes about open access. College \& Research Libraries 70(4), 315-335. .

Sale, A. (2006). Researchers and institutional repositories. In Open Access: Key Strategic, Technical and Economic Aspects, ed. Neil Jacobs, (pp.87-98). Oxford: Chandos Press. 
Schonfeld, R.C. \& Housewright,R. (2010). Faculty survey 2009: Key strategic insights for libraries, publishers, and societies. New York: Ithaka S + R. Retrieved May 1, 2010, from http://www.ithaka.org/ithaka-s-r/research/faculty-surveys-2000-2009/

Swan, A. and S. Brown (Key Perspectives, Ltd.). (2004). Joint Information Systems Committee (JISC) and the Open Society Institute (OSI) Journal Authors Survey Report. Retrieved March 15, 2010 from http://www.jisc.ac.uk/media/documents/themes/infoenvironment/acf655.pdf

Willinsky, John. (2005). The access principle: the case for open access to research and scholarship.

Cambridge: MIT Press.

\section{APPENDIX}

\section{AUTHOR SURVEY: Open Access Publishing in Business Research}

\section{Your age in years:}

$\square$ Under 30
$31-45$
$\square$
$46-50$
$\square \quad$ Over 60

\section{Please indicate your academic status:}

Tenured

$\square$ Tenure track

- Non-Tenure track

- Retired/Emeritus

$\square$ Other (please specify)

3. How many articles have you published in your scholarly career thus far?

Fewer than 5

口 5-10

口 $11-20$

- More than 20

4. How important are the following in your decision on where to publish journal articles?

\begin{tabular}{|l|c|c|c|c|c|}
\hline & $\begin{array}{c}\text { Not } \\
\text { Important } \\
1\end{array}$ & 2 & $\begin{array}{c}\text { Neutral } \\
3\end{array}$ & 4 & $\begin{array}{c}\text { Very } \\
\text { Important } \\
5\end{array}$ \\
\hline Reputation of Journal & & & & & \\
\hline $\begin{array}{l}\text { Citation impact (ex. } \\
\text { ISI impact factor) }\end{array}$ & & & & & \\
\hline
\end{tabular}




\begin{tabular}{|l|l|l|l|l|l|}
\hline $\begin{array}{l}\text { Journal is Peer } \\
\text { reviewed }\end{array}$ & & & & & \\
\hline $\begin{array}{l}\text { Quality of } \\
\text { Editor/editorial board }\end{array}$ & & & & & \\
\hline Acceptance Rate & & & & & \\
\hline $\begin{array}{l}\text { Timeliness of } \\
\text { publication process }\end{array}$ & & & & & \\
\hline $\begin{array}{l}\text { Published by } \\
\text { scholarly society or } \\
\text { association }\end{array}$ & & & & & \\
\hline $\begin{array}{l}\text { Influenced by my } \\
\text { grant-awarding body }\end{array}$ & & & & & \\
\hline $\begin{array}{l}\text { Ability to retain } \\
\text { copyright to your } \\
\text { work }\end{array}$ & & & & & \\
\hline $\begin{array}{l}\text { My manuscript is a } \\
\text { good match for the } \\
\text { journal }\end{array}$ & & & & & \\
\hline $\begin{array}{l}\text { I've published there } \\
\text { before }\end{array}$ & & & & & \\
\hline
\end{tabular}

5. When you need full-text journal articles for your own research, where do you most often obtain them?

Through my college/university library (either in print or electronically)

I have personal subscriptions to the journals I need

Articles or pre-prints sent by colleagues

F Freely available on the Internet

$\square$ Other (please specify

6. You are searching for articles for your own research. Please rank the following in relative importance to you as you gather these.

\begin{tabular}{|c|c|c|c|c|c|}
\hline & $\begin{array}{c}\text { Not } \\
\text { Important } \\
1\end{array}$ & 2 & $\begin{array}{c}\text { Neutral } \\
3\end{array}$ & 4 & $\begin{array}{c}\text { Very } \\
\text { Important } \\
5\end{array}$ \\
\hline Reputation of Journal & & & & & \\
\hline
\end{tabular}




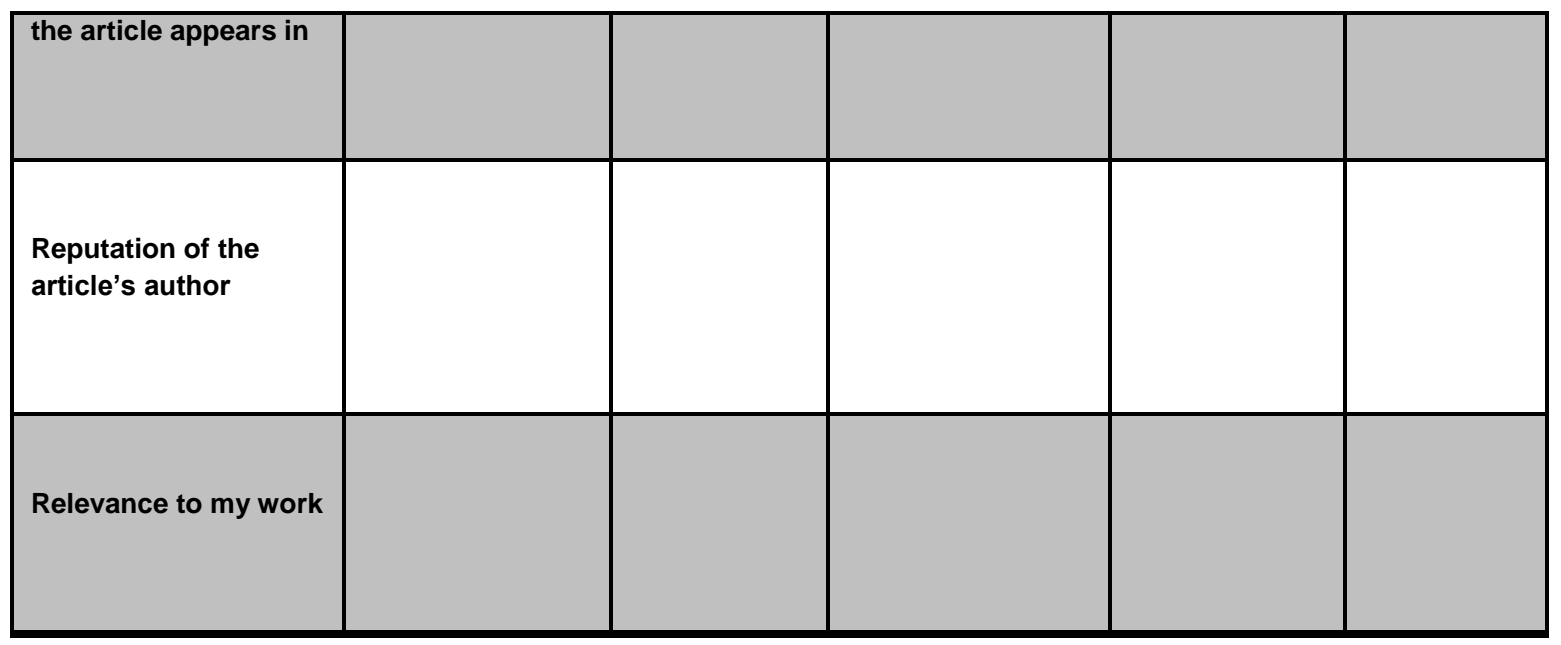

7. In your DISCIPLINE, for purposes of tenure and/or promotion, publication in electronic journals of any kind is:

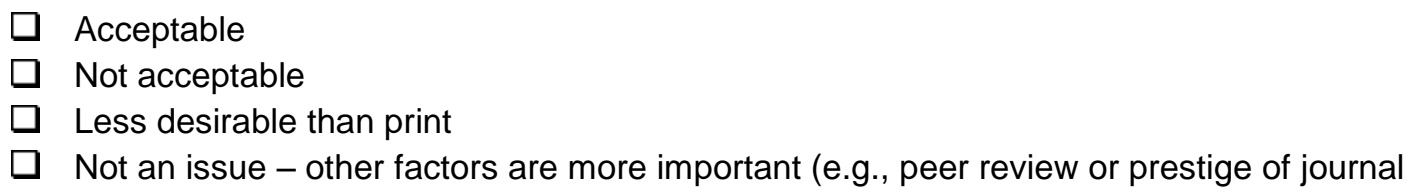

8. Within your INSTITUTION/DEPARTMENT, for purposes of tenure and/or promotion, publication in electronic journals of any kind is:

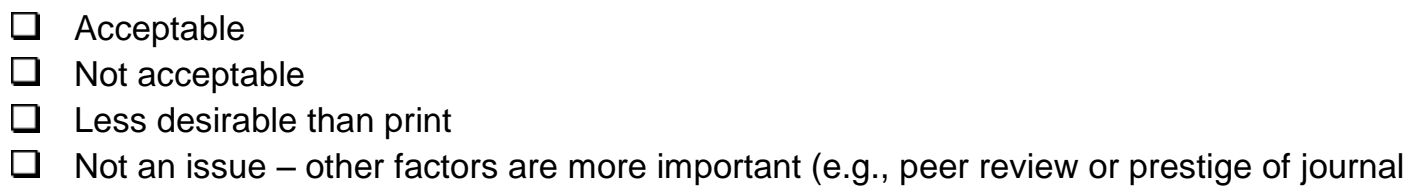

9. Please indicate the importance of the following publications for tenure/promotion and /or advancement in your discipline:

\begin{tabular}{|l|c|c|c|c|c|}
\hline & $\begin{array}{c}\text { Not } \\
\text { Important } \\
1\end{array}$ & 2 & $\begin{array}{c}\text { Neutral } \\
3\end{array}$ & 4 & $\begin{array}{c}\text { Very } \\
\text { Important } \\
5\end{array}$ \\
\hline Books/Monographs & & & & & \\
\hline Book Reviews & & & & & \\
\hline Peer Reviewed Journal & & & & & \\
\hline
\end{tabular}




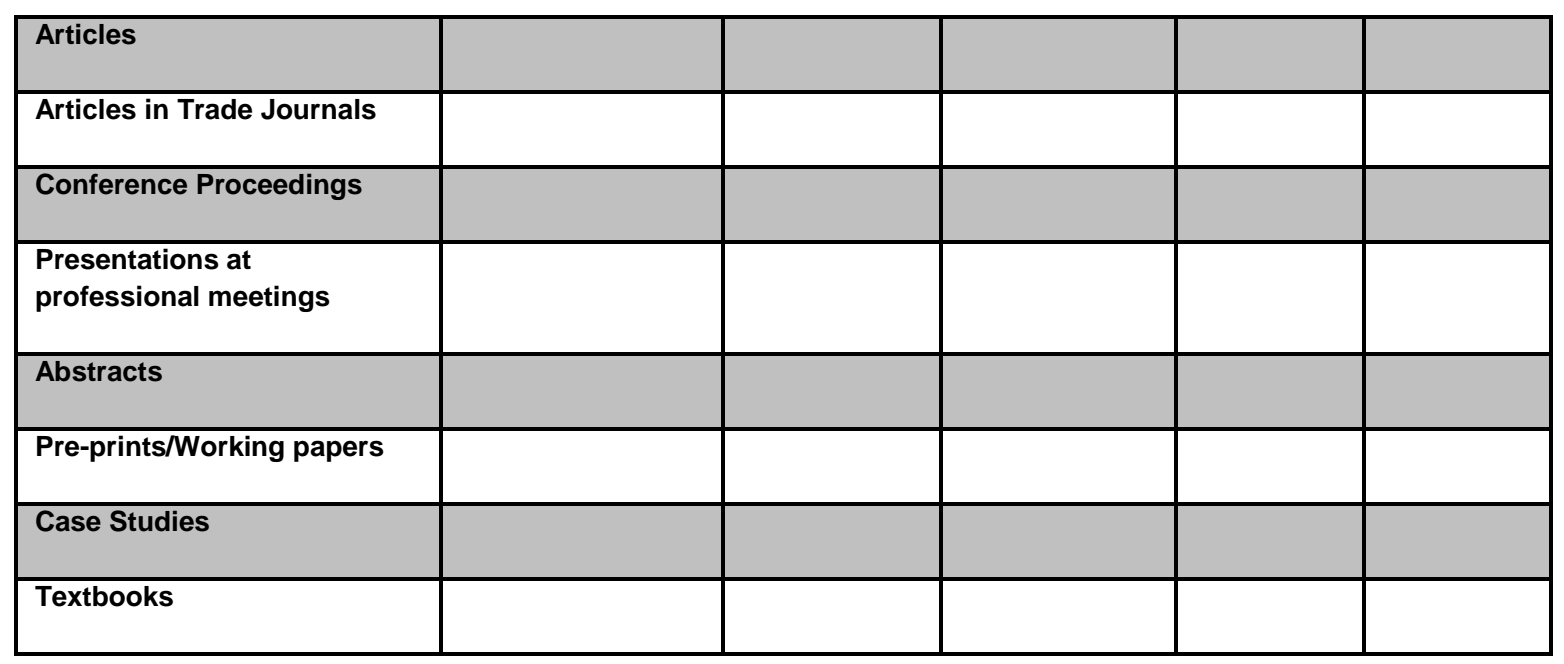

10. How did you become aware of open access publishing? Please check all that apply.

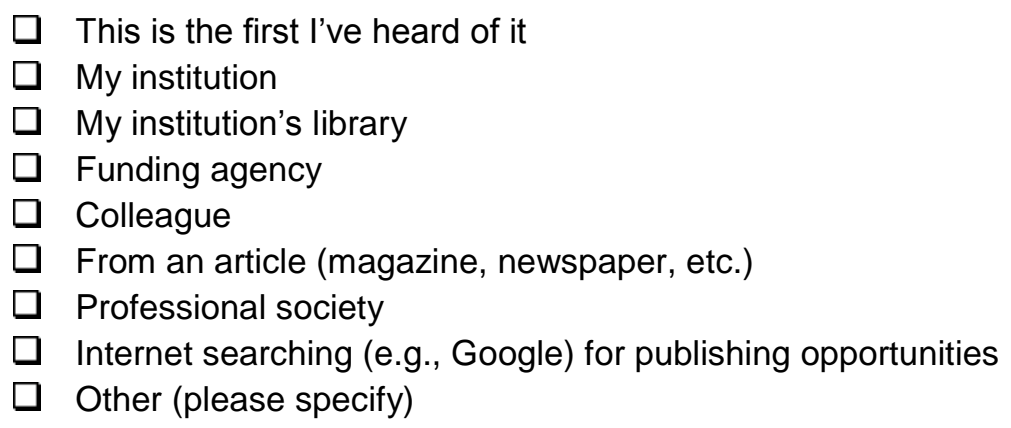

11. Please respond to these perceptions of open access (OA) publishing.

\begin{tabular}{|l|l|l|l|l|}
\hline & True & False & $\begin{array}{c}\text { Depends } \\
\text { on the journal }\end{array}$ & No Opinion \\
\hline OA means free access for all readers & & & & \\
\hline $\begin{array}{l}\text { OA journals have faster publication } \\
\text { times }\end{array}$ & & & & \\
\hline Readership will be larger & & & & \\
\hline Articles will be more frequently cited & & & & \\
\hline $\begin{array}{l}\text { OA publishing will help reduce cost } \\
\text { of journal subscriptions }\end{array}$ & & & & \\
\hline $\begin{array}{l}\text { OA journals are less prestigious than } \\
\text { subscription-based journals }\end{array}$ & & & & \\
\hline OA journals will not be properly & & & & \\
\hline
\end{tabular}




\begin{tabular}{|l|l|l|l|l|}
\hline archived & & & & \\
\hline $\begin{array}{l}\text { OA journals may adversely affect the } \\
\text { viability of scholarly societies }\end{array}$ & & & & \\
\hline $\begin{array}{l}\text { May adversely affect chances at } \\
\text { promotion }\end{array}$ & & & & \\
\hline $\begin{array}{l}\text { OA journals are usually not peer } \\
\text { reviewed }\end{array}$ & & & & \\
\hline
\end{tabular}

Comments:

12. Some (both $O A$ and non-OA) journals, in the sciences particularly, require author publication fees. Please indicate which of the following most closely mirrors your thoughts on this model.

Have published in a journal that required author fees

Have not done so, but I would

Have not done so but I would, depending on the journal and/or the purpose of the fee

Would do so if my funding agency or institution paid for it

Would not publish in a journal that requires publication fees

Comments:

13. Have you self-archived any of your publications (on a personal website, an institutional repository, e-print archive, etc.)?

$\square$ Yes

No

14. If you answered "yes" to the question above (Question \#13) why did you self-archive?

To make my research more widely available

- Believe it will increase the impact of my research

D Decision influenced by my institution/department/library

Decision influenced by my grant-awarding body

Decision influenced by my co-author(s)

$\square$ Other (please specify)

15. If you answered "no" to the self-archiving question above (Question \#13) why have you chosen not to self-archive?

Did not actively choose not to - it hasn't come up

- Not convinced it would be an advantage to do so

- Not certain copyright allows it

My institution does not have a repository available

Not sure where or how to do so

I I don't have time 
$\square$ Other (please specify)

16. This survey was e-mailed to authors working in a number of different academic areas within the broader discipline of business. Of the choices below, which most closely represents your primary area of endeavor?
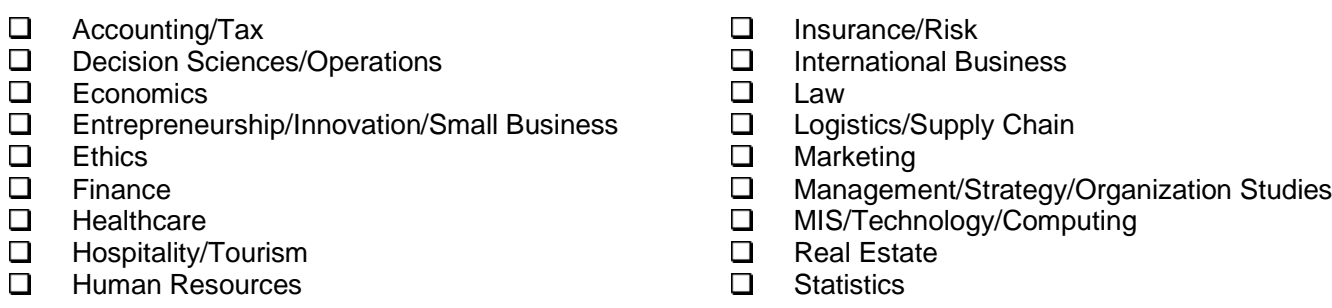

17. Your additional comments are welcome. 